\title{
Don't burn our flag: patriotism, perceived threat, and the impact of desecrating a national symbol on intergroup attitudes
}

\author{
Gaëlle Marinthe $^{2,1}$ (D) Benoit Testé ${ }^{2} \cdot$ Rodolphe Kamiejski $^{2}$
}

Accepted: 31 March 2021 / Published online: 17 April 2021

(C) The Author(s) 2021

\begin{abstract}
Desecration of national symbols is a recurring societal phenomenon that can lead to highly defensive reactions from some citizens, especially on the part of those expressing a strong attachment to the nation. In this paper, we investigated the effects of blind and constructive patriotism when faced with an ingroup (vs. outgroup) national flag burning on ingroup bias, taking into consideration the mediating role of perceived threat. In two studies $(N=252)$, the level of blind patriotism predicted stronger ingroup bias - due to more negative evaluation of visible minorities and/or more positive evaluation of the ingroup-when another ingroup member burnt an ingroup (vs. outgroup) flag. This effect was partly mediated by a greater threat to the group's image perceived by blindly patriotic people when the ingroup (vs. outgroup) flag was burnt (Study 2). Study 2 also highlighted a main effect of the symbol: ingroup bias was stronger when the ingroup (vs. outgroup) flag was burnt. We discuss the implications of our findings with respect to the role played by modes of national attachment and the consequences of desecrating symbols.
\end{abstract}

Keywords Flag desecration $\cdot$ Intergroup attitudes $\cdot$ National symbols $\cdot$ Patriotism $\cdot$ Social identity

Throughout the world, controversies regularly erupt over the desecration of national symbols. Whether they are motivated by a protest against political institutions (such as the breach of the Capitol following Biden's election in the United States (US), Kanno-Youngs, 2021; or flag burning during strikes, Welch, 2000); by a desire to fight racism (for example, NFL players kneeling during the national anthem, Mather \& Belson, 2018); or done in the name of art (for example, the photo of a man using the French flag as toilet paper, Vey, 2010), these desecrations are the subject of societal debates, widely reported in the media. In relation to all of these cases, some citizens defend the right to desecrate national symbols in the name of freedom of speech, while others advocate respect for the nation, and through its symbols, its memory, values and unity (Welch, 2000).

This article is based on the dissertation completed by Marinthe (2020).

Gaëlle Marinthe

gmarinthe@swps.edu.pl

1 Department of Psychology, SWPS University of Social Sciences and Humanities, 03-815 Warszawa, Poland

2 Laboratoire de psychologie : cognition, comportement, communication, Université Rennes 2, Place Recteur Henri le Moal, 35000 Rennes, France
National symbols are official representations of a nation around which a country's citizens can unite (Mach, 1993). For many citizens, the symbol (e.g., flag) becomes indissociable from the nation and is considered a sacred object that must be defended (Durkheim, 2013; Tzanelli, 2006). Most countries protect their national symbols through legislation banning their destruction or violation, which reinforces citizens' own informal rules regarding what is acceptable. Such informal rules exist even in countries where desecrating national symbols is permitted, such as the United States, but where disrespect for national symbols (e.g., kneeling during the national anthem) still provokes controversy and rekindles the debate over whether such acts should be banned (see Mather \& Belson, 2018). In France, where the desecration of national symbols has been banned since 2003, incidents still occur, leading to angry protests and calls for punishment from some citizens and politicians (e.g., Roos, 2008). Reactions to attacks on symbols, such as urging people to respect their country (e.g., Le Pen, 2019; Trump, 2017), reflect the desire to protect not only the symbol, but also the national group it embodies. Thus, by reinforcing the desire to protect the national group, these attacks could, by extension, affect relations with minority and national outgroups (Marinthe et al., 2020). Yet while symbol desecration is frequently highlighted in the media, little research has been done on what factors explain the potential consequences of these acts. The present work examines 
how intragroup symbol desecration (i.e., by an ingroup member) may affect intergroup relations (i.e., evaluation of the ingroup and/or devaluation of minority outgroups). More precisely, we investigate how such effects may appear based on the individual's mode of attachment to the nation (blind patriotism or constructive patriotism), which may trigger a perception of threat when faced with the ingroup (vs. outgroup) flag being burnt.

\section{The Role of Modes of Attachment to the National Group}

Since desecrating a symbol is a mark of disrespect to the nation and a challenge to the group's values, people who are deeply attached to the values of national loyalty and protecting the nation are likely to perceive such acts as a particularly strong threat to the nation (Welch, 2000). In other words, perceptions of the threat posed by an attack on a national symbol may differ according to an individual's mode of attachment to the nation. As such, the distinction between blind patriotism and constructive patriotism (Schatz \& Staub, 1997) may be particularly apposite for studying the impact of attacks on symbols.

Blind and constructive patriotism are two ways of identifying with the national group, both of which are linked to attachment to symbolic representations of the nation (Golec de Zavala et al., 2016; Schatz et al., 1999). Blind patriotism describes a mode of attachment based on conservative values and a desire to maintain the status quo (Livi et al., 2014; Schatz et al., 1999). Blindly patriotic individuals are extremely loyal to the ingroup and will not countenance any criticism of it. Constructive patriotism, on the other hand, is a mode of attachment that allows for change within the group and encourages dissidence if it enables the nation to improve (Schatz et al., 1999; Schatz \& Staub, 1997). Constructive patriotism is positively linked to universalist values and negatively linked to conservative values (Livi et al., 2014).

As expressions of attachment to the nation, both blind patriotism and constructive patriotism are linked to positive evaluation of the ingroup (Schatz, 2018; Schatz \& Staub, 1997). In contrast, the two forms of patriotism differ in their relationship to the perception of threat to the nation, tolerance of national transgressions, and intergroup attitudes (Schatz, 2018). Blind patriotism is related to greater ingroup bias, i.e., to positive differentiation between the ingroup (evaluated more positively) and outgroups (evaluated more negatively) (e.g., Henderson-King et al., 2009). This positive distinction between the ingroup and outgroups is especially strong in response to a perception of threat to the nation, where blind patriots display increased hostility toward outgroups and visible minorities (e.g., Pehrson \& Green, 2010). Blindly patriotic individuals are particularly prone to perceiving a threat from outgroups (e.g., cultural contamination), but also from the ingroup, for example because of a critical attitude toward the nation of an ingroup member (Golec de Zavala et al., 2016; Schatz et al., 1999). Golec de Zavala et al. (2016, Study 3) conducted a study among Polish participants on their perceptions of and reaction to a film about Poland's responsibility for crimes against Jews during World War II (WWII) (whereas Poland had for a long time only presented itself as a victim of WWII). The most blindly patriotic people perceived this film as more insulting to Poland, and expressed more hostility and willingness to punish its directors. Constructive patriotism, on the other hand, was not linked to the perception of insult or to hostility expressed toward the filmmakers.

Constructive patriotism has a more complex relationship with the defense of the nation and favoring of the ingroup. It is generally not related to perceived threat to the national group or to ingroup bias (e.g., Golec de Zavala et al., 2016; Henderson-King et al., 2009; Schatz et al., 1999), and may even be related to more positive attitudes toward outgroups (e.g., Willis-Esqueda et al., 2017). However, when the nation is actually threatened, constructive patriotism, just like blind patriotism, seems to be a vector of greater protection of the nation (Depuiset \& Butera, 2003). Depuiset and Butera show that blind and constructive patriotism are not correlated when French individuals are faced with a law favoring the ingroup (non-threatening context), but do correlate positively when faced with a law favoring outgroups (threatening context), suggesting that constructive patriotism may correspond to a defensive attachment with the nation when the context is deleterious for the ingroup.

Given their characteristics, blind and constructive patriots could react differently to ingroup (vs. outgroup) symbol desecration by ingroup individuals.

\section{Ingroup Symbol Desecration: a Threat to Social Identity among Blind Patriots}

National symbols are functional because they highlight a national group's cohesion and distinctiveness (Mach, 1993), thereby enabling individuals to maintain a satisfactory social identity (Tajfel \& Turner, 1979). Hence, just as exposure to national symbols affects intergroup processes (Butz, 2009), their desecration can impact ingroup bias (Marinthe et al., 2020).

Desecrating the national symbols of the ingroup is seen as immoral (Haidt et al., 1993) and as an act of disloyalty and disrespect toward the national group (Graham et al., 2011; Welch, 2000). On the other hand, desecrating the symbol of an outgroup violates the norm of non-aggression toward other groups (Crandall et al., 2002; Thürmer \& McCrea, 2021). Thus, desecration of both an ingroup and an outgroup symbol 
can be considered an act of deviance, varying in degree depending on the emphasis placed on either the norm of loyalty or of non-aggression of outgroups, respectively. In a context where the norm of group loyalty and symbols are particularly valued (i.e., a context of sports competition; see Travaglino et al., 2014; Vargas-Salfate et al., 2020; von Scheve et al., 2014), being faced with an ingroup (vs. outgroup) flag being burnt by ingroup perpetrators causes an increase in ingroup bias among other ingroup members (Marinthe et al., 2020). In this set of studies, Marinthe et al. showed that this increase in bias was due both to more positive evaluation of the ingroup and to devaluation of outgroups. The authors suggest that, in a context of intergroup competition, the desecration of an ingroup (vs. outgroup) symbol may pose a threat to social identity, leading individuals to defend their national identity by positively differentiating their nation from others (Marinthe et al., 2020). While this effect appears in a context of competition that values loyalty to the ingroup, it could also appear as a function of individual variables, and more particularly according to the level of blind patriotism.

Due to the particular value placed on loyalty and symbols by blindly patriotic people (e.g., Schatz et al., 1999), they may be especially prone to perceiving moral deviance on the part of the member of the ingroup desecrating a national symbol (Pinto et al., 2010; Travaglino et al., 2014). Group morality is one of the main criteria on which individuals positively evaluate their ingroup (Leach et al., 2007). An ingroup member perceived as immoral thus creates a sense of threat to the image of the group among other ingroup members (Brambilla et al., 2013), and leads them to react to protect that image (Chekroun \& Nugier, 2011). As mentioned above, one common reaction to a threat to social identity is to express greater ingroup bias, i.e., to strengthen positive differentiation between the ingroup and outgroups (Branscombe et al., 1999). Thus, in response to the threat to the ingroup's image caused by ingroup flag burning, blind patriots could defend their national identity through an increase in ingroup bias. In other words, when facing an ingroup symbol being desecrated by a member of the ingroup (i.e., an internal threat coming from the deviance of a group member), the reaction of other ingroup members could have repercussions on intergroup attitudes and the evaluation of outgroups (see Greenaway \& Cruwys, 2018, for similar arguments).

In contrast, constructive patriots would be expected to tolerate protests against their group and thus put less emphasis on rigid loyalty to the nation (Schatz et al., 1999). The desecration of an ingroup symbol should not therefore be perceived as immoral and threatening. The impact of constructive patriotism may however be more complex, as it may depend on the severity of the threat. Given that group members are reluctant to show dissent when the group faces a severe threat (Penic et al., 2016), constructive patriots may also be less tolerant of protests against the ingroup in such circumstances (Depuiset
\& Butera, 2003). Given that constructive patriotism is linked to attachment to the nation and its symbols (Golec de Zavala et al., 2016), constructive patriots may perceive desecration of a national symbol as a severe threat to the ingroup and therefore react by defending the national group, even though they are usually tolerant of criticism.

\section{Overview and Hypotheses}

Although members threatening their ingroup are part of the life of social and national groups, investigations of the intergroup consequences of these threats are relatively rare (Greenaway \& Cruwys, 2018). The literature suggests that attacks on both ingroup and outgroup national symbols by an ingroup member could be perceived as deviant and therefore lead to a perception of a threat to national identity. Blind patriots, however, may be particularly prone to feel threatened by the desecration of an ingroup symbol, which violates the norm of group loyalty valued by these individuals. Consequently, and in order to defend their group identity, blindly patriotic people may increase their expression of ingroup bias, i.e., positive differentiation between their ingroup and outgroups. In general, groups with a migrant background are targeted for hostility in response to national threats (McLaren, 2003). More specifically, in France, groups from visible minorities (African and Asian) are particularly discriminated against (e.g., Eberhardt \& Simon, 2017). We therefore focus in this paper on how the desecration of national symbols could affect relations with socially devalued outgroups (from visible minorities) and reinforce ingroup bias toward them.

The role of constructive patriotism, on the other hand, is less certain. Constructive patriots are generally tolerant of criticism, so they may see an attack on a national symbol as less threatening and therefore feel less need to defend their social identity. However, if they perceive the attack to be sufficiently threatening, they may also adopt ingroup protection strategies.

The present studies investigated the link between blind and constructive patriotism and ingroup bias when faced with the desecration of an ingroup (vs. outgroup) symbol. We examined the role of blind patriotism and symbol desecration on ingroup bias by testing the following two hypotheses:

H1: The effect of blind patriotism on ingroup bias is moderated by the symbol desecrated. We expected more blindly patriotic (vs. less blindly patriotic) people to express greater ingroup bias (i.e., more positive differentiation between evaluations of the ingroup and visible minorities) when an ingroup (vs. outgroup) symbol is desecrated (Studies 1 and 2).

$\mathrm{H} 2$ : We expected this moderation to be mediated by the threat to the group's image, with the more blindly patriotic people perceiving a greater threat to the group's image when an ingroup (vs. outgroup) symbol is 
desecrated than the less blindly patriotic people, explaining the increase in ingroup bias (Study 2), cf. Fig. 1.

Our studies also enabled us to explore whether or not constructive patriotism triggers ingroup protection reactions. Constructive patriotism could accentuate the ingroup bias (H3a) or, on the contrary, reduce it (H3b) in response to desecration of an ingroup (vs. outgroup) symbol.

\section{Study 1}

Study 1 examined the consequences of the desecration by an ingroup member of a national symbol (ingroup vs. outgroup) on ingroup bias depending on the levels of blind and constructive patriotism. To manipulate the desecration of the symbol, we presented participants with a newspaper article about a flag, either French or Moroccan, being burnt by a French man. We chose the Moroccan flag because it is easily recognizable as a flag of a foreign outgroup (presence of the star of Islam on the flag). Moreover, this flag is familiar in France because of the presence of a large Moroccan community (Insee, 2019), and relations between France and Morocco are rather stable and harmonious ("Between Morocco and France, relations are still going strong," 2018). A pre-test $(N=43)$ confirmed these elements, showing that the Moroccan flag was recognized by the majority of participants $(62 \%)$, and was considered less representative of themselves than the French flag, $z=5.58, p<.001$. Feelings towards this symbol, although less positive than for the French flag, were nevertheless above the average for the scale $(M=4.10, S D=$ 1.61, on a 7-point scale). This flag thus allowed us to test the impact of a desecration of an ingroup vs. outgroup flag, with greater credibility of the inductions while minimizing the intergroup conflicts that may be latent. This study tested the hypotheses 1 and 3 presented in the overview. We expected a stronger ingroup bias when the ingroup (vs. outgroup) flag is burnt among the most blindly patriotic people (H1). We explored the potential role of constructive patriotism (H3).

\section{Method}

\section{Population}

This study was conducted with a convenience sample of 101 first-year psychology and physical education undergraduates at the University of Rennes 2 (France). Excluding participants who were born outside France $(n=5)$ or whose mother tongue was not French $(n=2)$ gave us a final sample of 96 people $(62$ women, 34 men), aged between 18 and 25 years $(M=20.05$, $S D=1.48)$. This sample enabled us to detect a weak to medium effect size $\left(f^{2}=.08\right)$ with an alpha of $0.05 \%$ and a power of .80 in a multiple regression analysis testing one predictor out of five (G*Power, Faul et al., 2007).

\section{Procedure}

We informed participants that the study comprised three separate sections, each involving a paper questionnaire. The first questionnaire was presented as assessing perceptions of France and was designed to measure participants' attachment to France ${ }^{1}$ (identification, blind patriotism, constructive patriotism). When they had completed this questionnaire, we gave them the second questionnaire, which we presented as examining how the media shape perceptions of news. It began with a press article about an individual convicted of desecrating a national symbol. This article was created for the study but was inspired by a real article ("First Conviction for Contempt of Flag," 2010). ${ }^{2}$ Our fictitious article described a man belonging to the French ingroup who had burnt a French flag (ingroup symbol condition, $n=48$ ), or a Moroccan flag (outgroup symbol condition, $n=48$ ). ${ }^{3}$ Following this induction, participants completed a filler questionnaire about the media (including questions on the perception of the article and of different French newspapers, and on their media consumption). The third questionnaire examined perceptions of different social groups and included measures of intergroup attitudes. Finally, we asked participants to provide sociodemographic information.

\section{Measures}

Unless otherwise indicated, responses were given on sevenpoint Likert scales, ranging from 1: 'Strongly disagree' to 7: 'Strongly agree'. The items measuring blind and constructive patriotism were taken from Rothì et al. (2005) and translated into French using the translation/back-translation procedure.

Blind Patriotism Eleven items evaluated blind patriotism (e.g., "I would support my country right or wrong"), $\alpha=0.89$.

Constructive Patriotism Ten items measured constructive patriotism (e.g., "It is the duty of a good citizen to express their discontentment with the national decisions."), $\alpha=0.91$.

Identification with the Group of French People Five items (Dambrun, 2001) measured level of identification with the

\footnotetext{
${ }^{1}$ Both studies included other measures but they did not concern the objectives of the present paper, so they are not reported here.

${ }^{2}$ The experimental materials can be found at: https://osf.io/5psmf/.

${ }^{3}$ A third condition was also present, manipulating the ingroup flag being burnt by a member of the Moroccan outgroup. In order to keep our point clear and concise, and because no effect of the membership of the perpetrator or of its interaction with other variables was observed, we do not report analyses including this condition.
} 


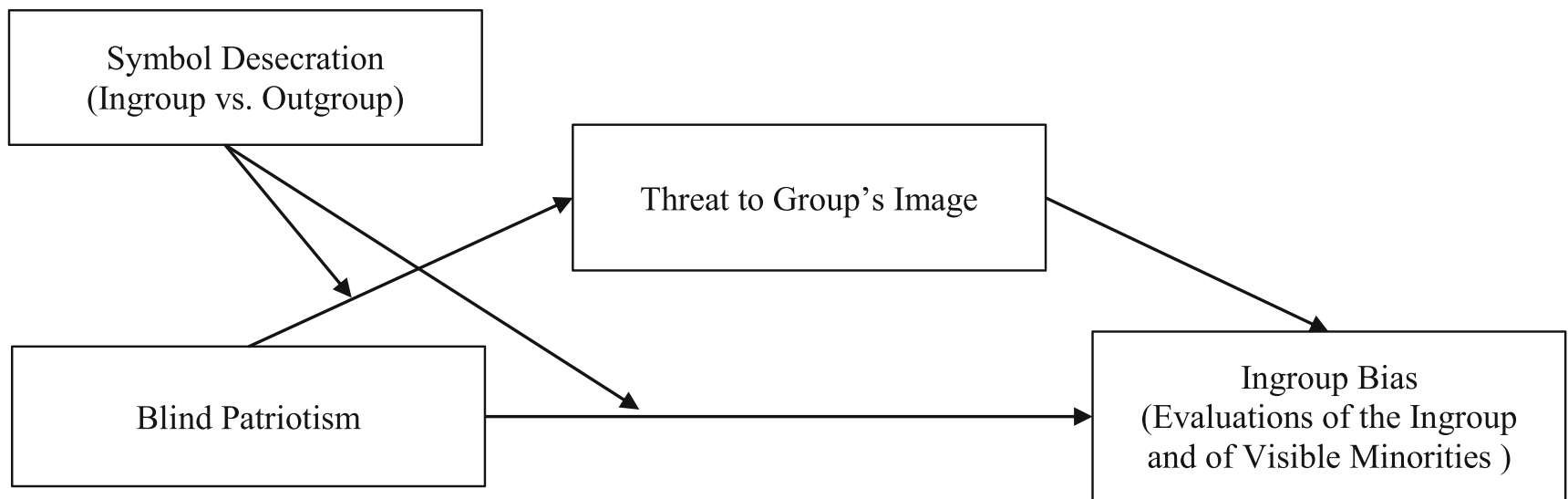

Fig. 1 Representation of the expected moderated mediation (H2)

group of French people (e.g., "The group of French people is an important group for me"), $\alpha=0.91$.

Intergroup Attitudes We used the feeling thermometer method (as used in France by Mahfud et al., 2015, for example) to calculate ingroup bias, i.e., the difference between the evaluations of the ingroup and of visible minorities. Participants evaluated a series of social groups, including our target groups, on 11-point scales from 1: 'Very unfavorable' to 11: 'Very favorable'. In order to control for individual differences in the use of the scale, the evaluation score for each group corresponds to the difference between the raw evaluation of the target group and the overall mean of the raw evaluations of all groups (see Wilcox et al., 1989). A positive (negative) difference showed that a target group was evaluated more positively (less positively) than the groups as a whole. This gave us evaluation scores for the ingroup (French) and two outgroups, both of which are visible ethnic minorities in France (North Africans and Asians). We then calculated the ingroup bias (evaluation of the French group - evaluation of visible minority groups). Overall, the visible minorities were evaluated more negatively than the ingroup, $F(1,95)=$ $11.07, p<.001, \eta_{\mathrm{p}}^{2}=.10$.

Table 1 shows means and standard deviations for the dependent variables in total (for all variables) and for each condition (for the dependent variables), ${ }^{4}$ and correlations between variables.

\section{Results $^{5}$}

We conducted regression analyses for intergroup attitudes (ingroup bias, evaluation of the ingroup, evaluation of visible minorities) with blind patriotism (standardized score), constructive patriotism (standardized score), symbol (coded -1 :

\footnotetext{
${ }^{4}$ The levels of blind patriotism, constructive patriotism, and identification did not differ between conditions, all $F s(1,94)<1.59$, ps $>.211, \eta_{\mathrm{p}}^{2}<.02$.

5 The data and syntax for the two studies, as well as the tests for regression assumptions, can be found at: https://osf.io/5psmf/.
}

outgroup symbol condition, +1: ingroup symbol condition, see Koslowsky, 1988; Ravenscroft \& Buckless, 2017), and the interaction of each patriotism with the symbol, testing $\mathrm{H} 1$ and H3. Results are reported in Table 2.

As can be seen from Table 2, blind patriotism was related to more ingroup bias, due to a better evaluation of the ingroup and to more negative evaluation of visible minorities. Moreover, and as expected, the interaction between blind patriotism and symbol had a significant effect, but only for evaluation of the visible minorities. The results of decomposing this interaction supported our hypothesis: the effect of symbol was significant for the most blindly patriotic participants, who evaluated the visible minorities more negatively when the ingroup (vs. outgroup) flag was burnt $(+1 S D), \beta=-0.42$, $t=-3.00, p=.003, \eta_{\mathrm{p}}^{2}=.09$, but it was not significant for the least blindly patriotic participants $(-1 S D), \beta=0.11, t=$ $0.79, p=.432, \eta_{\mathrm{p}}^{2}=.01$, cf. Fig. 2 .

No effect of constructive patriotism or its interaction with the symbol has been found.

\section{Discussion}

Study 1 showcased that, overall, blind patriotism was a strong predictor of intergroup attitudes. Moreover, the results supported H1, as we observed an effect of the interaction between blind patriotism and symbol attacked on intergroup attitudes: the most blindly patriotic individuals evaluated the visible minorities more negatively when the ingroup (vs. outgroup) symbol was desecrated. We did not find any interaction effect with constructive patriotism (thus supporting neither H3a nor $\mathrm{H} 3 \mathrm{~b})$.

Study 1 showed that, although blind patriotism is linked to more expression of differentiation between the ingroup and the visible minorities, certain conditions, such as attacks on national symbols, moderate this effect. An intragroup desecration of their national symbol leads the most blindly patriotic French people to express greater hostility towards visible minority groups. We expected this effect to be the result of a 
Table 1 Means, standard deviations and correlations (Study 1, N=96)

\begin{tabular}{|c|c|c|c|c|c|c|c|c|c|}
\hline Variables & $\begin{array}{l}\text { Total } \\
M(S D)\end{array}$ & $\begin{array}{l}\text { Ingroup symbol } \\
M(S D)\end{array}$ & $\begin{array}{l}\text { Outgroup symbol } \\
M(S D)\end{array}$ & 1 & 2 & 3 & 4 & 5 & 0 \\
\hline 1. Blind Patriotism & $\begin{array}{l}2.31 \\
(0.99)\end{array}$ & & & 1 & & & & & \\
\hline 2. Constructive Patriotism & $\begin{array}{l}5.60 \\
(0.91)\end{array}$ & & & $-.29 * *$ & 1 & & & & \\
\hline 3. Identification & $\begin{array}{l}4.71 \\
(1.19)\end{array}$ & & & $.59 * * *$ & -.07 & 1 & & & \\
\hline 4. Evaluation of the Ingroup & $\begin{array}{l}0.22 \\
(1.43)\end{array}$ & $\begin{array}{l}0.27 \\
(1.73)\end{array}$ & $\begin{array}{l}0.16 \\
(1.06)\end{array}$ & $.34 * *$ & -.08 & $.26^{*}$ & 1 & & \\
\hline 5. Evaluation of the Visible Minorities & $\begin{array}{l}-0.40 \\
(0.84)\end{array}$ & $\begin{array}{l}-0.54 \\
(1.03)\end{array}$ & $\begin{array}{l}-0.25 \\
(0.58)\end{array}$ & $-.35 * *$ & .07 & -.15 & $-.22 *$ & 1 & \\
\hline 6. Ingroup bias & $\begin{array}{l}0.61 \\
(1.81)\end{array}$ & $\begin{array}{l}0.81 \\
(2.18)\end{array}$ & $\begin{array}{l}0.42 \\
(1.33)\end{array}$ & $.43 * * *$ & -.10 & $.28 * *$ & $.89 * * *$ & $-.64 * * *$ & \\
\hline
\end{tabular}

$*<.05 ; * *<.01 ; * * *<.001$

stronger perception of threat to the group's image (see Welch, 2000). Study 2 tested this hypothesis.

\section{Study 2}

Study 2 was designed to check the interaction effect between blind patriotism and symbol attacked obtained in Study 1 (H1), and to explore possible effects of the interaction between constructive patriotism and the symbol attacked on intergroup attitudes (H3), despite the absence of an effect in Study 1 . We also postulated that desecrating the ingroup symbol would constitute a threat to social identity, leading to greater perceived threat to the group's image in the most blindly patriotic people, thereby explaining the increase in ingroup bias (H2).

\section{Method}

\section{Population}

Participants were 170 students at University of Rennes 2 (France). Excluding participants who were born outside France $(n=13)$ and/or whose mother tongue was not French $(n=10)$ gave us a final sample of 156 people ( 137 women, 19 men), aged between 18 and 26 years $(M=19.86, S D=1.74)$.
Table 2 Multiple regression analyses (Study 1)

\begin{tabular}{llll}
\hline Predictors & Ingroup bias & Evaluation of the ingroup & $\begin{array}{l}\text { Evaluation of the } \\
\text { Visible minorities }\end{array}$ \\
\hline Blind patriotism & $.42^{* * *}$ & $.36^{* * *}$ & $-.30^{* *}$ \\
& {$[.22, .63]$} & {$[.14, .57]$} & {$[-.50,-.10]$} \\
Constructive patriotism & .03 & .03 & -.01 \\
& {$[-.17, .24]$} & {$[-.18, .25]$} & {$[-.22,19]$} \\
Symbol & .08 & .02 & -.15 \\
& {$[-.10, .27]$} & {$[-.18, .21]$} & {$[-.34, .04]$} \\
Blind patriotism x symbol & .09 & -.04 & $-.26^{*}$ \\
& {$[-.12, .29]$} & {$[-.26, .17]$} & {$[-.47,-.06]$} \\
Constructive patriotism x symbol & -.001 & .001 & .003 \\
& {$[-.21, .20]$} & {$[-.21, .22]$} & {$[-.20, .21]$} \\
$d d l$ model $F$ & $(5,90)$ & $(5,90)$ & $(5,90)$ \\
$R^{2}$ & .20 & .12 & .21 \\
$F$ & 4.56 & 2.45 & 4.82 \\
$p$ & .001 & .040 & .001 \\
\hline
\end{tabular}

The regression coefficients shown are standardized $(\beta)$. The numbers in square brackets correspond to the $95 \%$ confidence interval of the above regression coefficient

$* p<.05, * * p<.01, * * * p<.001$ 


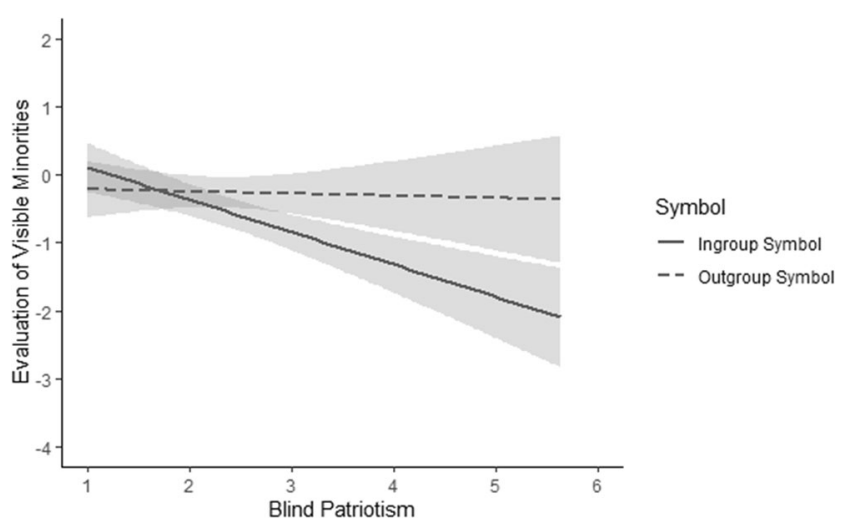

Fig. 2 Effect of the blind patriotism $x$ symbol interaction on evaluation of the visible minorities (Study 1)

This sample enabled us to detect a small effect size $\left(f^{2}=.05\right)$ with an alpha of $0.05 \%$ and a power of .80 in a multiple regression testing 1 predictor out of 7 (G*Power, Faul et al., 2007).

\section{Procedure}

We used a similar procedure to Study 1. Participants were exposed to the same experimental conditions: ingroup symbol $(n=76)$ and outgroup symbol $(n=80)$. We added a measure of perceived threat to the group's image. The order of the measures of threat and intergroup attitudes was counterbalanced to control for any effect of the order in which these measures were completed.

\section{Measures}

Variables from Study 1 We used the same measures of blind patriotism, $\alpha=0.89$, constructive patriotism, $\alpha=0.84$, identification, $\alpha=0.92$, evaluation of the ingroup, evaluation of the visible minorities, and ingroup bias. Again, the visible minorities were evaluated more negatively than the ingroup, $F(1,155)=17.08, p<.001, \eta_{\mathrm{p}}^{2}=.10$.

Perceived Threat We measured perceived threat to the ingroup's image via three items adapted from Brambilla et al. (2013, e.g., "This act threatens the reputation of French people"), evaluated on 7-point Likert scales, from 1: 'Strongly disagree', 7: 'Strongly agree', $\alpha=.85$.

Table 3 shows means and standard deviations in total (for all variables) ${ }^{6}$ and for each condition (for the mediator and dependent variables), and correlations between variables.

\footnotetext{
${ }^{6}$ Levels of blind patriotism, constructive patriotism, and identification with the group of French people did not differ between conditions, all $F_{s}(3152)<1.95, p s>.123, \eta_{\mathrm{p}}^{2}<.04$
}

\section{Results}

\section{Effects of Patriotism and Symbol on Intergroup Attitudes}

For all the following analyses, we coded the ingroup symbol +1 and the outgroup symbol -1 (see Koslowsky, 1988; Ravenscroft \& Buckless, 2017).

As in Study 1, we performed multiple regressions of intergroup attitudes. Blind patriotism (standardized score), constructive patriotism (standardized score), symbol, and the interactions between each type of patriotism and symbol were considered as predictors (testing $\mathrm{H} 1$ and $\mathrm{H} 3$ ), counterbalanced order (coded $-1=$ intergroup attitudes then threat, $+1=$ threat then intergroup attitudes) was added as a covariate, see Table 4.

As in Study 1, blind patriotism was related to more ingroup bias, due to a more positive evaluation of the ingroup and more negative evaluation of visible minorities. The blind patriotism $\mathrm{x}$ symbol interaction had a significant effect on ingroup evaluation and on ingroup bias. Decomposing this interaction showed that the most blindly patriotic people (+1 $S D$ ) expressed stronger ingroup bias, $\beta=.37, t=3.53, p=.001, \eta_{\mathrm{p}}^{2}=.08$, and evaluated the ingroup more positively, $\beta=.36, t=3.44, p=.001, \eta_{\mathrm{p}}^{2}=.07$, when the ingroup (vs. outgroup) flag was burnt. On the other hand, we did not observe any effect of symbol among the least blindly patriotic participants $(-1 S D)$, all $|t s|<0.13, p s>.527, \eta_{p}^{2} s<.01$ (see Figs. 3 and 4). Although the blind patriotism $x$ symbol interaction had no significant effect on the evaluation of the visible minorities, decomposing this interaction (see Tybout et al., 2001) revealed an identical pattern, with a more negative evaluation of the visible minorities in the ingroup (vs. outgroup) symbol condition for the most blindly patriotic participants $(+1 S D), \beta=-.24$, $t=-2.12, p=.035, \eta_{\mathrm{p}}^{2}=.03$, but no effect for the least blindly patriotic $(-1 S D), \beta=-.12, t=-1.06, p=.289, \eta_{\mathrm{p}}^{2}=.01$.

Again, no effect of constructive patriotism and of its interaction with the symbol being burnt has been observed.

In contrast to Study 1, symbol had an effect on bias against the visible minorities: bias was stronger when the ingroup (vs. outgroup) flag was burnt, due to a more positive evaluation of the ingroup and a more negative evaluation of the visible minorities.

\section{Mediation of the Blind Patriotism x Symbol Interaction on Intergroup Attitudes}

We hypothesized that the effect of the blind patriotism $\mathrm{x}$ symbol interaction on intergroup attitudes would be mediated by perceptions of threat to group's image (H2).

We used PROCESS (Hayes, 2013, model 8) to carry out mediation analyses with blind patriotism as the independent variable, symbol as the moderating variable, and perceived threat as the mediating variable. ${ }^{7}$ Constructive patriotism, its

\footnotetext{
${ }^{7}$ Complete regression analyses on perceived threat can be found at: https://osf. io $/ 5 \mathrm{psmf} /$.
} 
Table 3 Means, standard deviations and correlations (Study 2, N = 156)

\begin{tabular}{|c|c|c|c|c|c|c|c|c|c|c|}
\hline Variables & $\begin{array}{l}\text { Total } \\
M(S D)\end{array}$ & $\begin{array}{l}\text { Ingroup symbol } \\
M(S D)\end{array}$ & $\begin{array}{l}\text { Outgroup symbol } \\
M(S D)\end{array}$ & 1 & 2 & 3 & 4 & 5 & 6 & 7 \\
\hline 1. Blind patriotism & $\begin{array}{l}2.06 \\
(0.89)\end{array}$ & & & 1 & & & & & & \\
\hline 2. Constructive patriotism & $\begin{array}{l}5.64 \\
(0.82)\end{array}$ & & & $-.26 * *$ & 1 & & & & & \\
\hline 3. Identification & $\begin{array}{l}4.15 \\
(1.34)\end{array}$ & & & $.40 * * *$ & -.04 & 1 & & & & \\
\hline 4. Perceived group's image threat & $\begin{array}{l}4.50 \\
(1.78)\end{array}$ & $\begin{array}{l}3.67 \\
(1.69)\end{array}$ & $\begin{array}{l}5.29 \\
(1.50)\end{array}$ & $.22 * *$ & .06 & $.31 * * *$ & 1 & & & \\
\hline 5. Evaluation of the ingroup & $\begin{array}{l}0.28 \\
(1.28)\end{array}$ & $\begin{array}{l}0.50 \\
(1.47)\end{array}$ & $\begin{array}{l}0.04 \\
(1.03)\end{array}$ & $.36 * * *$ & -.09 & $.32 * * *$ & .11 & 1 & & \\
\hline 6. Evaluation of the visible minorities & $\begin{array}{l}-0.37 \\
(1.00)\end{array}$ & $\begin{array}{l}-0.55 \\
(1.15)\end{array}$ & $\begin{array}{l}-0.19 \\
(0.80)\end{array}$ & $-.27 * *$ & .05 & $-.20 *$ & -.09 & $-.39 * * *$ & 1 & \\
\hline 7. Ingroup bias & $\begin{array}{l}0.63 \\
(1.91)\end{array}$ & $\begin{array}{l}1.05 \\
(2.21)\end{array}$ & $\begin{array}{l}0.23 \\
(1.47)\end{array}$ & $.38 * * *$ & -.09 & $.32 * * *$ & .12 & $.88 * * *$ & $-.79 * * *$ & \\
\hline
\end{tabular}

interaction with symbol, and counterbalanced order were added as covariates. We applied a confidence interval of $95 \%$ and 5000 bootstrap iterations. We performed these analyses on ingroup bias and evaluation of the ingroup, as these were the attitudes that the most blindly patriotic participants reinforced in response to an attack on the ingroup symbol.

First of all, symbol had a main effect on perceived threat to group's image, $\beta=-.46, t=-6.94, p<.001, \eta_{\mathrm{p}}^{2}=.24$, being higher when the flag of the outgroup (vs. ingroup) is burnt. Moreover, the blind patriotism $\mathrm{x}$ symbol interaction had a significant effect on perceived threat, $\beta=.25, t=3.60$, $p<.001, \eta_{\mathrm{p}}^{2}=.08$. The simple effects of symbol on perceived threat were significant in both the least $(-1 S D)$ and most $(+1$ $S D)$ blind patriots, all $|t s|>2.19, p s<.030, \eta_{\mathrm{p}}^{2} \mathrm{~s}>.03$. Decomposing the interaction according to symbol showed that blind patriotism predicted greater perceived threat when the ingroup flag, $\beta=.49, t=5.22, p<.001, \eta_{\mathrm{p}}^{2}=.15$, but not the outgroup flag, $\beta=-.0002, t=-0.002, p=.998, \eta^{2}$ $<.001$, was burnt, cf. Fig. 5 .

Perceived threat to the group's image did not predict the evaluation of the ingroup, $b=0.18$, $s e(b)=0.11, t=1.54$, $p=.126,95 \%$ CI $[-0.05,0.40]$, nor did it mediate the effect of blind patriotism $x$ symbol on it, $b=0.09$, se $(b)=0.07,95 \%$ CI $[-0.001,0.25]$. Conversely, we found a moderated
Table 4 Multiple regression analyses (Study 2)

\begin{tabular}{llll}
\hline Predictors & Ingroup bias & Evaluation of the ingroup & $\begin{array}{l}\text { Evaluation of the } \\
\text { visible minorities }\end{array}$ \\
\hline Blind patriotism & $.38^{* * *}$ & $.35^{* * *}$ & $-.28^{* *}$ \\
& {$[.23, .53]$} & {$[.20, .50]$} & {$[-.44,-.12]$} \\
Constructive patriotism & .02 & .01 & -.02 \\
& {$[-.13, .17]$} & {$[-.14, .16]$} & {$[-.19, .14]$} \\
Symbol & $.22^{* *}$ & $.19^{*}$ & $-.18^{*}$ \\
& {$[.08, .36]$} & {$[.04, .33]$} & {$[-.34,-.03]$} \\
Symbol x blind patriotism & $.15^{*}$ & $.18^{*}$ & -.06 \\
& {$[.002, .30]$} & {$[.03, .33]$} & {$[-.22, .10]$} \\
Symbol x constructive patriotism & .11 & .12 & -.05 \\
& {$[-.04, .26]$} & {$[-.03, .27]$} & {$[-.21, .11]$} \\
Order & -.12 & $-.13 \dagger$ & .06 \\
& {$[-.26, .03]$} & {$[-.27, .02]$} & {$[-.10, .22]$} \\
$d d l$ model $F$ & $(6149)$ & $(6149)$ & $(6149)$ \\
$R^{2}$ & .23 & .21 & .11 \\
$F$ & 7.33 & 6.47 & 3.18 \\
$p$ & $<.001$ & $<.001$ & .006 \\
\hline
\end{tabular}

The regression coefficients shown are standardized $(\beta)$. The numbers in square brackets correspond to the $95 \%$ confidence interval of the above regression coefficient

$\dagger p<.10, * p<.05, * * p<.01, * * * p<.001$ 


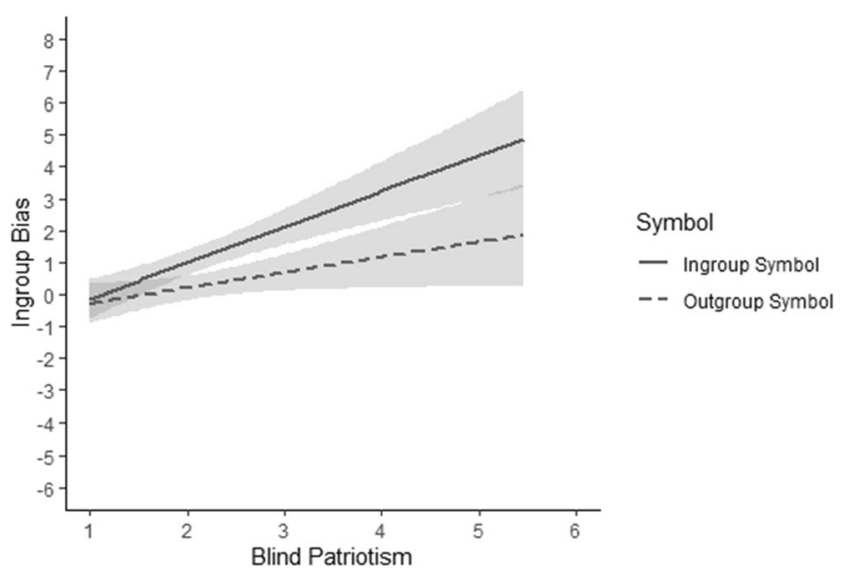

Fig. 3 Effect of the blind patriotism $\mathrm{x}$ symbol interaction on ingroup bias (Study 2)

mediation effect for ingroup bias, $b=0.16$, se $(b)=0.11,95 \%$ CI $[0.001,0.46]$. The indirect effect of blind patriotism on ingroup bias via perceived threat seemed greater in the ingroup symbol condition, $b=0.16$, se $(b)=0.11,95 \% \mathrm{CI}$ $[-0.02,0.40]$, than in the outgroup symbol condition, $b=$ $-0.0001, \operatorname{se}(b)=0.05,95 \%$ CI $[-0.10,0.11]$. An analysis with a confidence interval of $90 \%$ supported this hypothesis, as the mediation effect was marginally significant in the ingroup symbol condition, $b=0.16$, se $(b)=0.11,90 \%$ CI $[0.01$, $0.35]$, but not in the outgroup symbol condition, $b=$ $-0.0001, s e(b)=0.05,90 \%$ CI $[-0.08,0.09]$. Hence, the most blindly patriotic participants tended to perceive a greater threat to the group's image than the least blindly patriotic participants when the ingroup symbol was burnt, and this perceived threat explained the increased ingroup bias. We did not observe such a mediation effect when the outgroup symbol was burnt (see Fig. 6).

\section{Discussion}

In line with $\mathrm{H} 1$, the interaction between blind patriotism and the symbol impacted the evaluation of the ingroup and ingroup bias. The effect on ingroup bias was explained by

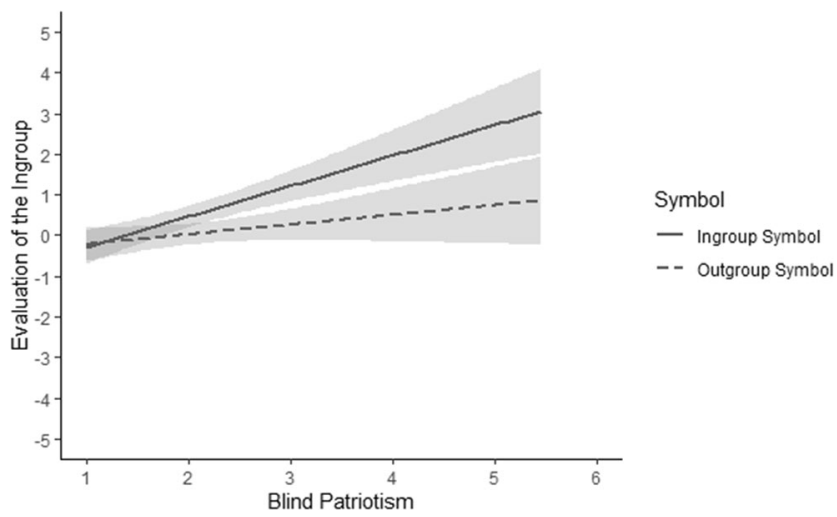

Fig. 4 Effect of the blind patriotism $\mathrm{x}$ symbol interaction on evaluation of the ingroup (Study 2)

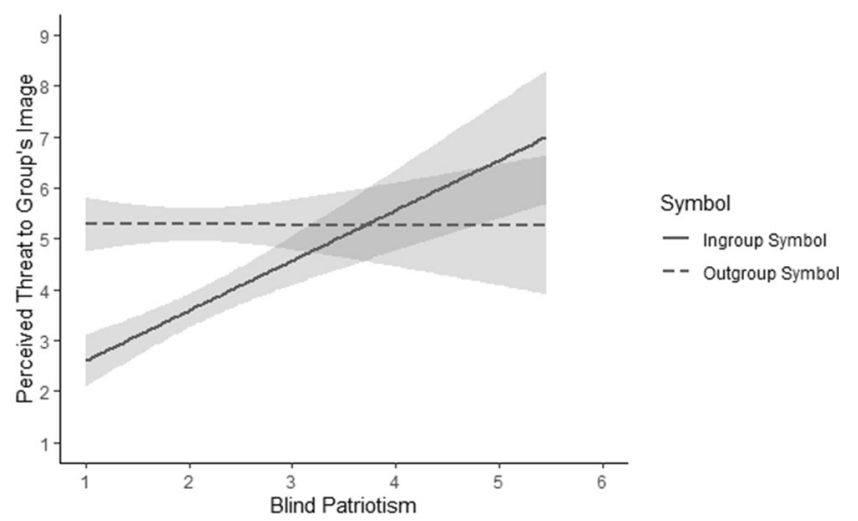

Fig. 5 Effect of the blind patriotism $\mathrm{x}$ symbol interaction on perceived threat to the group's image (Study 2)

greater perceived threat to the group's image, the link between blind patriotism and ingroup bias being marginally significant when the ingroup symbol was burnt (H2). More specifically, overall, the perceived threat to the group's image felt was greater when participants were faced with a member of the ingroup burning the Moroccan flag compared to the French flag. On the other hand, this difference decreased and became non-significant among the most blindly patriotic people, leading to an increase in ingroup bias in this condition. Moreover, as in Study 1, we did not obtain any effect from the interaction between constructive patriotism and the symbol attacked (H3). Finally, in contrast to Study 1, Study 2 revealed a main effect of the symbol on intergroup attitudes: ingroup bias was stronger when the ingroup (vs. outgroup) symbol was desecrated.

\section{General Discussion}

Our two studies examined the impact of being faced with an ingroup member desecrating a national symbol on intergroup attitudes, based on mode of attachment to the national group (blind and constructive patriotism). We expected greater differentiation between evaluations of the ingroup and visible minorities (i.e., ingroup bias) following desecration of the ingroup (vs. outgroup) symbol among the most blindly patriotic people (H1). Although blind patriotism was a robust predictor of intergroup attitudes in both studies, its effect was moderated by the flag being burnt, confirming $\mathrm{H} 1$. When faced with the ingroup (vs. outgroup) flag being burnt, the most blindly patriotic participants displayed a more negative evaluation of visible minorities in Study 1 and greater ingroup bias, mainly due to a more positive evaluation of the ingroup, in Study 2. This is partly explained by an increased perception of threat to the national ingroup's image among these participants (as hypothesized in H2). Finally, we explored the potential role of constructive patriotism when faced with desecration of a symbol (H3), but neither study revealed an effect 


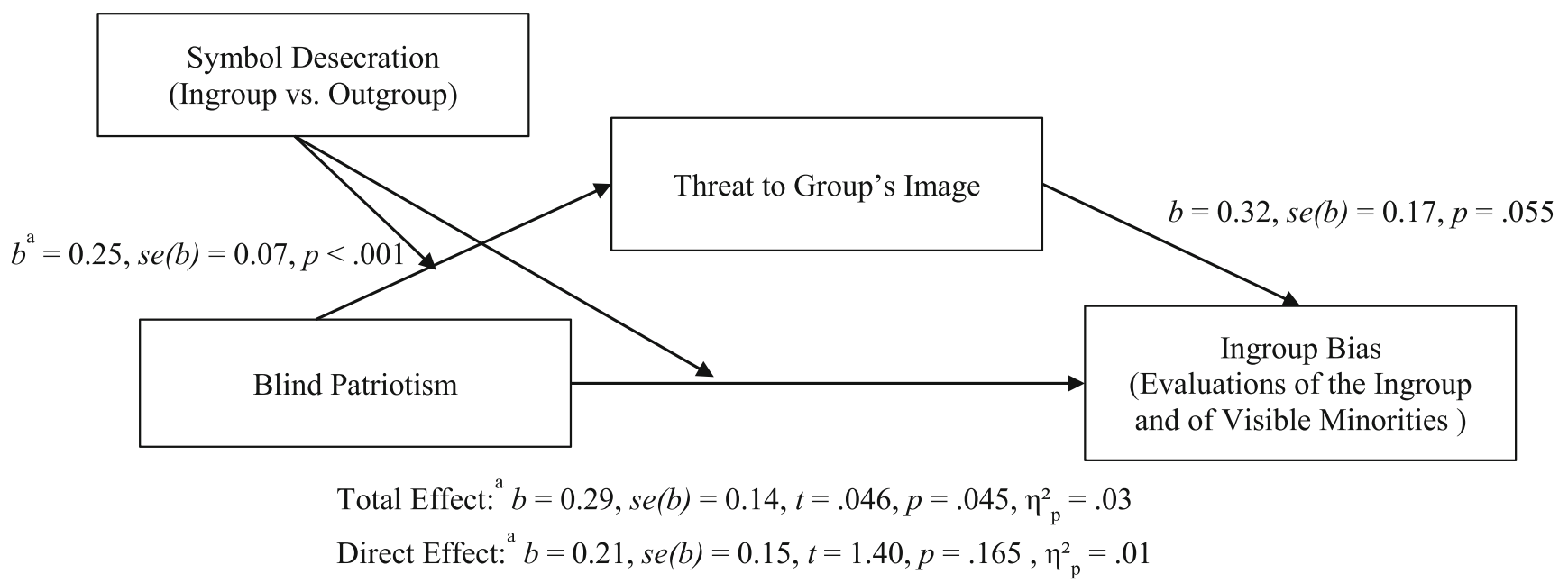

Fig. 6 Mediation of the effect of the blind patriotism $\mathrm{x}$ symbol interaction on ingroup bias by perceived threat to the group's image (Study 2$).$ Note. ${ }^{\text {a }}=$ effects for blind patriotism $\mathrm{x}$ symbol interaction

from this interaction. A main effect of the symbol being burnt was also seen in Study 2, in which participants expressed more ingroup bias, due to more positive evaluation of the ingroup and more negative evaluations of outgroups when the ingroup (vs. outgroup) flag was burnt.

\section{Symbol Desecration and Blind Patriotism}

The desecration of a symbol, whether of the ingroup or of the outgroup, can be perceived as an act of deviance when it is committed by a member of the ingroup. Desecration of an outgroup symbol violates the norm of non-aggression of other groups (Crandall et al., 2002; Thürmer \& McCrea, 2021) and may cause a threat to social identity, as shown by our results reporting a greater perceived threat to the group's image when an outgroup (vs. ingroup) flag is burnt. However, our studies confirm that the desecration of an ingroup symbol can also be threatening to certain individuals, who place particular emphasis on the norm of loyalty to the nation: the most blindly patriotic people. By generating a sense of threat to the image of the group, an intragroup act (the desecration of an ingroup symbol by a member of the ingroup) can therefore have consequences at the intergroup level, leading to increased differentiation between the ingroup and outgroups.

Our results show that the more blindly patriotic an individual, the more strongly that person defends their national identity following an attack on the ingroup symbol. This result is in line with Satherley et al. (2018), who showed that attachment to conservative values impacts the desire to protect national symbols (refusal to change the national flag). As well as this desire to protect symbols, our studies show that the most blindly patriotic people react to attacks on national symbols, perpetrated by an ingroup member, by evaluating visible minorities more negatively and thereby increasing positive differentiation between the ingroup and outgroups. Interestingly, the level of blind patriotism was relatively low in our samples. Hence, a high level of blind patriotism $(+1 S D)$ is actually below the midpoint of the scale. Although this low level appears to be stable across various French samples, and does not seem to be specific to student samples (see Marinthe, 2020), it may be lower than the levels reported in other countries, which range between 2.32 and 3.83 (on a 7-point scale) in American, British, and Polish samples (e.g., Golec de Zavala et al., 2016; Rothì et al., 2005; Willis-Esqueda et al., 2017). As can be seen, a low level of blind patriotism seems to be normative in France. This could be explained, among other things, by the history of WWII, which limits the normative expression of extreme and rigid identification with the national group, as observed in Germany, for example (Becker et al., 2012). However, our studies suggest that, rather than the absolute level of blind patriotism, the relative level (i.e., positioning in the national sample) would be more relevant for studying processes related to this mode of national attachment. Even a slightly higher expression of blind patriotism can lead citizens to be sensitive to threats to national identity and, particularly in our research, to attacks on national symbols.

In both of our studies, defense reactions to desecration of the ingroup flag were strongest among the most blindly patriotic participants. However, this defense was sometimes expressed through more negative evaluation of the visible minorities (Studies 1 and 2), and sometimes by greater ingroup bias and more positive evaluation of the ingroup (Study 2). These differences could be due to a difference in statistical power between the two studies, but could also be due more broadly to a change in the context in which the studies took place (see Amrhein et al., 2019). Such variations in the nature of the effects on the ingroup and outgroups, which were also reported by Marinthe et al. (2020) in situations of intergroup competitions, could be explained by the level of threat associated with the context. Study 1 was 
conducted in 2016, a time of great social unrest in France, with frequent strikes and demonstrations, and closer to the November 13, 2015 terrorist attacks in Paris. These events may have heightened the general feeling of threat in Study 1 compared to Study 2, which was carried out the following year. The marginally higher level of blind patriotism, $F(1.305)=3.72, p=.055, \eta_{\mathrm{p}}^{2}=.01$, in Study 1 than in Study 2 could be an indicator of this (see Li \& Brewer, 2004). These contextual differences may have affected the defense strategies (ingroup approval or outgroup derogation) employed by the most blindly patriotic participants in response to the desecration of their national symbol, particularly since we used explicit measures (a feeling thermometer) that are sensitive to context and social desirability (Maass et al., 2000). Using implicit measures in future studies would reduce the impact of context on indicators of intergroup attitudes, and thereby provide more stable results.

\section{Desecration of National Symbols as a Threat to Social Identity}

Our studies also shed light on the role of perceived threat for blindly patriotic people. In Study 2, the increased ingroup bias shown by the most blindly patriotic participants when the ingroup symbol was desecrated was explained by the greater perceived threat to the group's image. The higher their level of blind patriotism, the more individuals perceived a threat to their group image when the ingroup (vs. outgroup) symbol was desecrated, and this perception affected their intergroup attitudes. To our knowledge, there are no other studies examining the impact of moral deviance towards the ingroup (such as the deviance from loyalty examined in our studies) on intergroup attitudes. Our research highlights that people who strongly defend their national group may react to a threat, even if it emanates from within their ingroup, by developing an ingroup bias toward outgroups that are not responsible for the threat, more specifically socially rejected minorities. However, the mediation effect of threat to the group's selfimage is small and suggests there may be other mediators which could be investigated in future studies (e.g., threat to group's distinctiveness, Wohl et al., 2010).

Interestingly, participants in Study 2 showed greater ingroup bias (due to more positive evaluation of the ingroup and a devaluation of visible minorities) when their symbol was burnt than when an outgroup symbol was burnt. This suggests they were defending their social identity faced with an attack on their symbol even though the level of perceived threat to the group's image was higher for the outgroup flag being burnt. This result replicates the findings of Marinthe et al. (2020) from studies conducted in an intergroup competitive context and shows that attacks on national symbols can also affect intergroup relations in everyday situations, independently of the level of blind patriotism. Thus, attachment to national symbols, which is expressed explicitly in certain contexts (sporting competitions, times of conflict) could also be present outside these situations, as suggested by the idea of banal nationalism (Billig, 1995). We did not however find this effect in Study 1, which was less powered than Study 2. The marginally significant effect of the symbol on attitudes toward visible minorities in Study 1 suggests that more power might have enabled detection of an effect of the symbol, as in Study 2. It may also be that other processes that we did not control for (e.g., variations in the normativity of the expression of ingroup bias or in the meaning of national symbols, see Carter et al., 2020) may have come into play to accentuate the defense of ingroup symbols in Study 2.

\section{Limitations and Future Directions}

Although our studies confirmed our hypotheses 1 and 2, they are subject to a number of limitations. First, we used convenience student samples in both studies, which may differ from representative samples of the general population in terms of certain characteristics (e.g., personality traits, Hanel \& Vione, 2016). Nevertheless, we did observe in our studies the mechanisms hypothesized on the basis of the literature. There is therefore no evidence to suggest that the effects and mechanisms observed in our studies, particularly the interaction of blind patriotism with desecration of the ingroup symbol, are limited to a student population (see Stroebe et al., 2018), although future studies may verify this.

In addition, our studies were conducted on a French population. This French sample could partly explain the lack of effect of constructive patriotism (H3). Indeed, in our studies, constructive patriotism was unexpectedly unrelated to identification with the national ingroup, which prevents us from drawing firm conclusions about its role. As constructive patriotism is sensitive to a country's sociopolitical situation (Penic et al., 2016), the concept may not have the same meaning in France as in other countries.

The cultural context and therefore the prevailing social norms, may also impact on the effects of ideologies relating to national identity on intergroup relations (see Guimond et al., 2013). Hence, the influence on intergroup relations of both constructive patriotism (as suggested by Depuiset \& Butera, 2003; Penic et al., 2016) and blind patriotism may vary according to the legal and political context. In countries with strict laws protecting symbols (e.g., Israel), social norms against desecrating symbols are likely to be stronger. Conversely, in countries where citizens have the right to desecrate symbols (e.g., Norway), norms against desecrating symbols may be weaker. Blindly patriotic people may accord less importance to the desecration of symbols if such actions are only slightly counter-normative, and constructively patriotic people may react more strongly to such acts if they are strongly counter-normative. Consequently, our results must 
be interpreted in the light of France's legal and cultural context, in which desecration of national symbols is illegal and in which strongly defending symbols is associated with conservatism. Future studies could build on our results by examining the effects of cultural norms, and their interaction with different types of patriotism, on the defense of national symbols.

Our findings highlight the importance of national symbols for intergroup relations. Some citizens, based on their type of patriotism, are particularly sensitive to attacks on their national symbols. Such acts, even when committed by an ingroup member, can affect intergroup attitudes toward rejected visible minority outgroups as a result of group members' attempts to reduce the perceived threat to their social identity. Our studies also shed light on the different ways in which citizens react to attacks on their national symbols (e.g., France's "Yellow Vests" protestors defacing the Arc de Triomphe, the removal of public statues, the Capitol breach in the USA) and increase understanding of how these attacks can lead to hostile reactions to some country's minority groups.

Supplementary Information The online version contains supplementary material available at https://doi.org/10.1007/s12144-021-01696-6.

Code Availability (Software Application or Custom Code) Not applicable.

Authors' Contributions All authors contributed to the study conception and design. Material preparation, data collection and analyses were performed by Gaëlle Marinthe. The first draft of the manuscript was written by Gaëlle Marinthe and all authors commented on previous versions of the manuscript. All authors read and approved the final manuscript.

Data Availability The datasets generated during and analyzed during the current study are available in the OSF repository, https://osf.io/5psmf/.

\section{Declarations}

Ethics Approval Not applicable. This study does not have an ethics approval because there is no ethics committee at the university where the research was conducted. However, this study was performed in line with the principles of the Declaration of Helsinki and with the recommendations of the national ethics committee.

Consent to Participate Informed consent was obtained from all individual participants included in the study.

Consent for Publication Participants signed informed consent regarding publishing their data.

Conflicts of Interest/Competing Interests On behalf of all authors, the corresponding author states that there is no conflict of interest.

Open Access This article is licensed under a Creative Commons Attribution 4.0 International License, which permits use, sharing, adaptation, distribution and reproduction in any medium or format, as long as you give appropriate credit to the original author(s) and the source, provide a link to the Creative Commons licence, and indicate if changes were made. The images or other third party material in this article are included in the article's Creative Commons licence, unless indicated otherwise in a credit line to the material. If material is not included in the article's Creative Commons licence and your intended use is not permitted by statutory regulation or exceeds the permitted use, you will need to obtain permission directly from the copyright holder. To view a copy of this licence, visit http://creativecommons.org/licenses/by/4.0/.

\section{References}

Amrhein, V., Trafimow, D., \& Greenland, S. (2019). Inferential statistics as descriptive statistics: There is no replication crisis if we don't expect replication. The American Statistician, 73(sup1), 262-270. https://doi.org/10.1080/00031305.2018.1543137.

Becker, J. C., Enders-Comberg, A., Wagner, U., Christ, O., \& Butz, D. A. (2012). Beware of national symbols: How flags can threaten intergroup relations. Social Psychology, 43(1), 3-6. https://doi.org/10. 1027/1864-9335/a000073.

Billig, M. (1995). Banal nationalism. SAGE.

Brambilla, M., Sacchi, S., Pagliaro, S., \& Ellemers, N. (2013). Morality and intergroup relations: Threats to safety and group image predict the desire to interact with outgroup and ingroup members. Journal of Experimental Social Psychology, 49(5), 811-821. https://doi.org/ 10.1016/j.jesp.2013.04.005.

Branscombe, N. R., Ellemers, N., Spears, R., \& Doosje, B. (1999). The context and content of social identity threat. In N. Ellemers, R. Spears, \& B. Doosje (Eds.), Social identity: Context, commitment, content. (pp. 35-58). Blackwell Science.

Butz, D. A. (2009). National symbols as agents of psychological and social change. Political Psychology, 30(5), 779-804. https://doi. org/10.1111/j.1467-9221.2009.00725.x.

Carter, T. J., Pandey, G., Bolger, N., Hassin, R. R., \& Ferguson, M. J. (2020). Has the effect of the American flag on political attitudes declined over time? A case study of the historical context of American flag priming. Social Cognition, 38(6), 489-520. https:// doi.org/10.1521/soco.2020.38.6.489.

Chekroun, P., \& Nugier, A. (2011). "I'm ashamed because of you, so please, don't do that!": Reactions to deviance as a protection against a threat to social image. European Journal of Social Psychology, 41(4), 479-488. https://doi.org/10.1002/ejsp.809.

Crandall, C. S., Eshleman, A., \& O'Brien, L. (2002). Social norms and the expression and suppression of prejudice: The struggle for internalization. Journal of Personality and Social Psychology, 82(3), 359-378. https://doi.org/10.1037/0022-3514.82.3.359.

Dambrun, M. (2001). Dominance sociale et préjugés: La régulation sociale des cognitions sociales des cognitions intergroupes [Social dominance and prejudice: The social regulation of intergroup cognitions] [Unpublished doctoral dissertation]. Laboratoire de Psychologie Sociale de la Cognition, Université Blaise Pascal.

Depuiset, M.-A., \& Butera, F. (2003). The stability of patriotism in the face of variation in national laws. Psychologica Belgica, 43(1-2), $123-138$.

Durkheim, É. (2013). Les formes élémentaires de la vie religieuse: Le système totémique en Australie [The elementary forms of religious life] (7th ed.). Presses universitaires de France.

Eberhardt, M., \& Simon, P. (2017). Expérience et perception des discriminations en Île-de-France [experience and perception of discrimination in the Île-de-France region]. Observatoire régional des discriminations en Île-de-France. https://www.defenseurdesdroits.fr/sites/ default/files/atoms/files/synthese_ordis_idf_-experience_et perception des discriminations en idf.pdf

Entre le Maroc et la France, des relations toujours au beau fixe [Between Morocco and France, relations are still going strong]. (2018, August 27). Le Monde arabe. https://lemonde-arabe.fr/27/08/2018/marocfrance-relations-commerce-tourisme-economie/ 
Faul, F., Erdfelder, E., Lang, A.-G., \& Buchner, A. (2007). G*Power 3: A flexible statistical power analysis program for the social, behavioral, and biomedical sciences. Behavior Research Methods, 39(2), 175191. https://doi.org/10.3758/BF03193146.

Golec de Zavala, A., Peker, M., Guerra, R., \& Baran, T. (2016). Collective narcissism predicts hypersensitivity to in-group insult and direct and indirect retaliatory intergroup hostility. European Journal of Personality, 30(6), 532-551. https://doi.org/10.1002/ per.2067.

Graham, J., Nosek, B. A., Haidt, J., Iyer, R., Koleva, S., \& Ditto, P. H. (2011). Mapping the moral domain. Journal of Personality and Social Psychology, 101(2), 366-385. https://doi.org/10.1037/ a0021847.

Greenaway, K. H., \& Cruwys, T. (2018). The source model of group threat: Responding to internal and external threats. American Psychologist, 74(2), 218-231. https://doi.org/10.1037/ amp0000321.

Guimond, S., Crisp, R. J., De Oliveira, P., Kamiejski, R., Kteily, N., Kuepper, B., Lalonde, R. N., Levin, S., Pratto, F., Tougas, F., Sidanius, J., \& Zick, A. (2013). Diversity policy, social dominance, and intergroup relations: Predicting prejudice in changing social and political contexts. Journal of Personality and Social Psychology, 104(6), 941-958. https://doi.org/10.1037/a0032069.

Haidt, J., Koller, S. H., \& Dias, M. G. (1993). Affect, culture, and morality, or is it wrong to eat your dog? Journal of Personality and Social Psychology, 65(4), 613-628. https://doi.org/10.1037/00223514.65.4.613.

Hanel, P. H. P., \& Vione, K. C. (2016). Do student samples provide an accurate estimate of the general public? PLoS One, 11(12), e0168354. https://doi.org/10.1371/journal.pone.0168354.

Hayes, A. F. (2013). Introduction to mediation, moderation, and conditional Process analysis: A regression-based approach. Guilford Press.

Henderson-King, E., Henderson-King, D., \& Hathaway, L. (2009). Group favoritism and support for government policies as a function of patriotic orientation and perceived threat. Revue Internationale de Psychologie Sociale, 22(3-4), 235-266.

Insee. (2019). Immigrés selon le pays de naissance. Insee. https://www. insee.fr/fr/statistiques $/ 4177162$ ?sommaire $=4177618 \&$ geo $=$ FE-1

Kanno-Youngs, Z. (2021, January 13). Federal authorities warn that the Capitol breach will be a 'significant driver of violence.' The New York Times. https://www.nytimes.com/2021/01/13/us/politics/ capitol-breach-driver-of-violence.html

Koslowsky, M. (1988). Using effect coding for comparing models in social research. Social Behavior and Personality, 16(1), 85-90. https://doi.org/10.2224/sbp.1988.16.1.85.

Le Pen, M. (2019, August 6). Siffler un hymne national, en l'occurrence la Marseillaise, est toujours une honte, un affront et l'inverse des valeurs de fair-play. On attend de la FIFA qu'elle sanctionne la fédération de football turque pour le manque de respect du public turc ce soir. MLP \#TURFRA [Booing a national anthem, in this case the Marseillaise, is always a disgrace, an affront and the opposite of the values of fair play. FIFA is expected to sanction the Turkish Football Association for the lack of respect shown by the Turkish public tonight. MLP \#TURFRA] [Tweet]. @ MLP_officiel. https:// twitter.com/mlp officiel/status/1137433002705924096

Leach, C. W., Ellemers, N., \& Barreto, M. (2007). Group virtue: The importance of morality (vs competence and sociability) in the positive evaluation of in-groups. Journal of Personality and Social Psychology, 93(2), 234-249. https://doi.org/10.1037/0022-3514. 93.2.234.

Li, Q., \& Brewer, M. B. (2004). What does it mean to be an American? Patriotism, nationalism, and American identity after 9/11. Political Psychology, 25(5), 727-739. https://doi.org/10.1111/j.1467-9221. 2004.00395.x.
Livi, S., Leone, L., Falgares, G., \& Lombardo, F. (2014). Values, ideological attitudes and patriotism. Personality and Individual Differences, 64, 141-146. https://doi.org/10.1016/j.paid.2014.02. 040.

Maass, A., Castelli, L., \& Arcuri, L. (2000). Measuring prejudice: Implicit versus explicit techniques. In D. Capozza \& R. Brown (Eds.), Social identity processes: Trends in theory and research (pp. 96-116). Sage Publications Ltd. https://doi.org/10.4135/ 9781446218617.n7.

Mach, Z. (1993). Symbols, conflict, and identity: Essays in political anthropology. State University of New York Press.

Mahfud, Y., Badea, C., \& N'Gbala, A. (2015). Distance culturelle et préjugés à l'égard des immigrés en France: Le rôle des modèles d'intégration [Cultural distance and prejudice against immigrants in France: The role of integration models]. Revue Internationale de Psychologie Sociale, 28(2), 59-79.

Marinthe, G. (2020). Approche psycho-sociale des dégradations de symboles nationaux: Conséquences sur les relations intergroupes, implication de l'identification et des patriotismes [Psychosocial approach of national symbols' desecration: Consequences on intergroup relations, implication of identification and patriotism] [Unpublished doctoral dissertation]. University of Rennes 2.

Marinthe, G., Falomir-Pichastor, J. M., Testé, B., \& Kamiejski, R. (2020). Flags on fire: Consequences of a national symbol's desecration for intergroup relations. Group Processes \& Intergroup Relations, 23(5), 744-760. https://doi.org/10.1177/1368430219853352.

Mather, V., \& Belson, K. (2018, July 20). Surprise! The N.F.L. National Anthem Problem Is Not Going Away. The New York Times. https:// www.nytimes.com/2018/07/20/sports/nfl-national-anthemkneeling-protest.html

McLaren, L. M. (2003). Anti-immigrant prejudice in Europe: Contact, threat perception, and preferences for the exclusion of migrants. Social Forces, 81(3), 909-936. https://doi.org/10.1353/sof.2003. 0038.

Pehrson, S., \& Green, E. G. T. (2010). Who we are and who can join us: National identity content and entry criteria for new immigrants. Journal of Social Issues, 66(4), 695-716. https://doi.org/10.1111/j. 1540-4560.2010.01671.x.

Penic, S., Elcheroth, G., \& Reicher, S. (2016). Can patriots be critical after a nationalist war? The struggle Between recognition and marginalization of dissenting voices: Can patriots be critical after a nationalist war? Political Psychology, 37(4), 481-496. https://doi. org/10.1111/pops. 12262.

Pinto, I. R., Marques, J. M., Levine, J. M., \& Abrams, D. (2010). Membership status and subjective group dynamics: Who triggers the black sheep effect? Journal of Personality and Social Psychology, 99(1), 107-119. https://doi.org/10.1037/a0018187.

Première condamnation pour outrage au drapeau [First Conviction for Contempt of Flag]. (2010, December 22). Le Monde. https://www. lemonde.fr/societe/article/2010/12/22/premiere-condamnationpour-outrage-au-drapeau_1456880_3224.html

Ravenscroft, S. P., \& Buckless, F. A. (2017). Contrast coding in ANOVA and regression. In T. Libby (Ed.), The Routledge Companion to Behavioural Accounting Research (1st ed., pp. 349-372). Routledge. https://doi.org/10.4324/9781315710129-23.

Roos, A. (2008, October 16). "La Marseillaise” sifflée: Des précédents existent ["La Marseillaise" booed: precedents exist]. https://www. lemonde.fr/sport/article/2008/10/16/la-marseillaise-sifflee-desprecedents-existent $11079003242 . \mathrm{html}$

Rothì, D. M., Lyons, E., \& Chryssochoou, X. (2005). National Attachment and patriotism in a European nation: A British study. Political Psychology, 26(1), 135-155. https://doi.org/10.1111/j. 1467-9221.2005.00412.x.

Satherley, N., Osborne, D., \& Sibley, C. G. (2018). Who is for (or against) the National Flag? Ideological and identity-based 
motivators of attitudes. Analyses of Social Issues and Public Policy, 19(1), 407-428. https://doi.org/10.1111/asap.12169.

Schatz, R. T. (2018). A review and integration of research on blind and constructive patriotism. In M. Sardoc (Ed.), Handbook of Patriotism (pp. 1-19). Springer International Publishing. https://doi.org/10. 1007/978-3-319-30534-9 30-1.

Schatz, R. T., \& Staub, E. (1997). Manifestations of blind and constructive patriotism: Personality correlates and individual-group relations. In D. Bar-Tal \& E. Staub (Eds.), Patriotism: In the lives of individuals and nations (pp. 229-245). Nelson-Hall Publishers.

Schatz, R. T., Staub, E., \& Lavine, H. (1999). On the varieties of National Attachment: Blind versus constructive patriotism. Political Psychology, 20(1), 151-174. https://doi.org/10.1111/0162-895X. 00140.

Stroebe, W., Gadenne, V., \& Nijstad, B. A. (2018). Do our psychological Laws apply only to college students?: External validity revisited. Basic and Applied Social Psychology, 40(6), 384-395. https://doi. org/10.1080/01973533.2018.1513362.

Tajfel, H., \& Turner, J. C. (1979). An integrative theory of intergroup conflict. In S. Worchel \& W. Austin (Eds.), Psychology of intergroup relations (pp. 7-24). Nelson-Hall Publishers.

Thürmer, J. L., \& McCrea, S. M. (2021). Disentangling the intergroup sensitivity effect: Defending the Ingroup or enforcing general norms? European Journal of Social Psychology, ejsp.2748. https:// doi.org/10.1002/ejsp.2748.

Travaglino, G. A., Abrams, D., Randsley de Moura, G., Marques, J. M., \& Pinto, I. R. (2014). How groups react to disloyalty in the context of intergroup competition: Evaluations of group deserters and defectors. Journal of Experimental Social Psychology, 54, 178-187. https://doi.org/10.1016/j.jesp.2014.05.006.

Trump, D. J. (2017, October 18). The NFL has decided that it will not force players to stand for the playing of our National Anthem. Total disrespect for our great country! [Tweet]. @ realdonaldtrump. https://twitter.com/realdonaldtrump/status/920606910109356032? lang $=\mathrm{fr}$

Tybout, A., Sternthal, B., Keppel, G., Verducci, J., Meyers-Levy, J., Barnes, J., Maxwell, S., Allenby, G., Gupta, S., Steenkamp, J.-B., \& Maxwell, S. (2001). Analysis of variance. Journal of Consumer Psychology, 10(1), 5-35. https://doi.org/10.1207/ S15327663JCP1001\&2_03.
Tzanelli, R. (2006). 'Not my flag!' Citizenship and nationhood in the margins of Europe (Greece, October 2000/2003). Ethnic and Racial Studies, 29(1), 27-49. https://doi.org/10.1080/ 01419870500351217.

Vargas-Salfate, S., Paez, D., Oriol, X., da Costa, S., Gondim, S., \& Techio, E. (2020). Nationalistic collective rituals, intergroup relations, and legitimation of National Social Systems. International Review of Social Psychology, 33(1), 1. https://doi.org/10.5334/irsp. 291.

Vey, T. (2010, April 21). MAM veut punir l'auteur d'un outrage au drapeau présumé [MAM wants to punish the perpetrator of an alleged flag offense]. Le Figaro. https://www.lefigaro.fr/actualitefrance/2010/04/21/01016-20100421ARTFIG00526-mam-veutpunir-1-auteur-d-un-outrage-au-drapeau-presume-.php

von Scheve, C., Beyer, M., Ismer, S., Kozłowska, M., \& Morawetz, C. (2014). Emotional entrainment, national symbols, and identification: A naturalistic study around the men's football world cup. Current Sociology, 62(1), 3-23. https://doi.org/10.1177/ 0011392113507463.

Welch, M. (2000). Flag burning: Moral panic and the criminalization of protest. Aldine de Gruyter.

Wilcox, C., Sigelman, L., \& Cook, E. (1989). Some like it hot: Individual differences in responses to group feeling thermometers. Public Opinion Quarterly, 53(2), 246-257. https://doi.org/10.1086/ 269505.

Willis-Esqueda, C., Delgado, R. H., \& Pedroza, K. (2017). Patriotism and the impact on perceived threat and immigration attitudes. The Journal of Social Psychology, 157(1), 114-125. https://doi.org/10. 1080/00224545.2016.1184125.

Wohl, M. J. A., Branscombe, N. R., \& Reysen, S. (2010). Perceiving your group's future to be in jeopardy: Extinction threat induces collective angst and the desire to strengthen the Ingroup. Personality and Social Psychology Bulletin, 36(7), 898-910. https://doi.org/10. 1177/0146167210372505.

Publisher's Note Springer Nature remains neutral with regard to jurisdictional claims in published maps and institutional affiliations. 